\title{
Investigate the Antibacterial Activity of Lichen Biomass Used in Textile Dye Removal
}

\author{
Ülküye Dudu Gül (Corresponding author) \\ Bilecik Seyh Edebali University, Vocational School of Health Sciences, Biotechnology \\ Application and Research Center, 11230, Bilecik, Turkey \\ Tel: +90(228)2141370Ｅ-mail: ulkuyedudugul@gmail.com
}

Received: June 8, 2020 Accepted: July 2, 2020

doi:10.5296/jbls.v11i2.17321 URL: https://doi.org/10.5296/jbls.v11i2.17321

\begin{abstract}
All over the world, the treatment of textile wastewater has become a significant problem due to the development of the textile industry. Particularly, the treatment of synthetic dyes, which are found abundantly amounts in textile wastewater, has gained importance. Recent studies have focused on the use of biological treatment technologies to remove pollutants in water. On the other hand, the disposal of wastes from biological treatment technologies was considered as another environmental problem. This study aims to compare the antimicrobial properties of the extract obtained from dye loaded and un-loaded lichen biomass after the biosorption process. According to the results of this study, it was found that the extract obtained from the waste lichen biomass, which has loaded with the textile dye in the decolorization process, showed a similar antimicrobial effect with the unloaded lichen extract. To sum up the waste lichen biomass used to remove textile dyes can be reused for the application of antimicrobial products.
\end{abstract}

Keywords: antimicrobial activity, waste biosorbent, lichen

\section{Introduction}

Recent studies have focused on the effects of various living organisms on the pathogenic microorganisms to treat infections (Necip \& Isik, 2019). Lichens are the organisms with a Mutualist lifestyle with a stable autotrophic feature formed by a mycobiont (a fungal species) and a photobiont (algae or cyanobacteria) (Özenoğlu et al., 2013). People have benefited from the lichens in medical approaches since ancient times. It is reported that lichens can be used in the treatment of many diseases such as systemic fungal infections, strengthening hair, urinary tract problems, and bone fractures (Oran \& Öztürk, 2006). For instance, the species 
belongs to the Usnea genus are used in the prevention of sweating, dizziness, colds, pain, and sputum formation, in the treatment of ulcers, intestinal disorders, in the treatment of lung problems and asthma (Halici et al., 2005). It was determined that the species belonging to this genus have a high antibacterial effect. Also, it has been determined that the species of Ramalina genus can be used for the production of natural dyes, and also they have antibacterial and antifungal activities (Çobanoğlu et al., 2004; Hanus et al., 2008).

In recent studies, it has been shown that the number of lichens reaches 1000 and many metabolites that are specific to lichens are synthesized by these lichen species (Özenoğlu et al., 2013). In the literature, these lichen metabolites have been reported with their antibiotics, antimycotic, antiviral, anti-inflammatory, analgesic, antipyretic, antiproliferative and cytotoxic effects (Rankovic et al. 2007; Şekerli et al., 2017). Studies in our country on antimicrobial activities of lichens are quite insufficient. According to my knowledge, in the literature, there is not any study about the antimicrobial effect of the lichen species called Evernia prunastri, which grows naturally in Bilecik province. In addition to this, no study shows the difference of antimicrobial activity by the dye loaded and unloaded lichen biomass. For this reason, in this study, the antimicrobial effect of ethanol extracts prepared from dye loaded and unloaded lichen biomass called E. prunastri collected from the city of Bilecik City Forest, against bacteria was determined using disc diffusion method. Since there are not many studies on this subject in the literature, it is expected that the findings obtained from this study will contribute to the literature.

\section{Material and Method}

\subsection{The Collection of Lichens and Preparation for Extraction}

The lichen species named Evernia prunastri was collected from the city forest of the Bilecik province (N $40^{\circ} 11.5262$ ', E $\left.029^{\circ} 57.962^{\prime}\right)$. The collected samples were washed in a laboratory environment and dried. The dried lichen biomass was used as a biosorbent to remove the textile dye called Acid Red 2PBX (AR) under optimal conditions. The optimal conditions ( $\mathrm{pH}$ : 2; Temperature: $25^{\circ} \mathrm{C}$; Time: 24 hours and initial dye concentration: $50 \mathrm{mg} /$ L, 100rpm shaking conditions) for dye removal were determined in the previous bioremediation studies was performed by the same lichen species (Unpublished Study).

The dye loaded lichen samples (dye absorbed lichen) were prepared in the same conditions and the unloaded lichen samples (not treated with dye) were used as the control group. The dye loaded and unloaded lichen samples were dried at $37^{\circ} \mathrm{C}$ in the oven and then the dried samples were powdered in the mortar to use for extraction. The photos of dye-loaded and unloaded E. prunastri samples used to obtain the extract was given in Figure 1. 


\section{Macrothink}

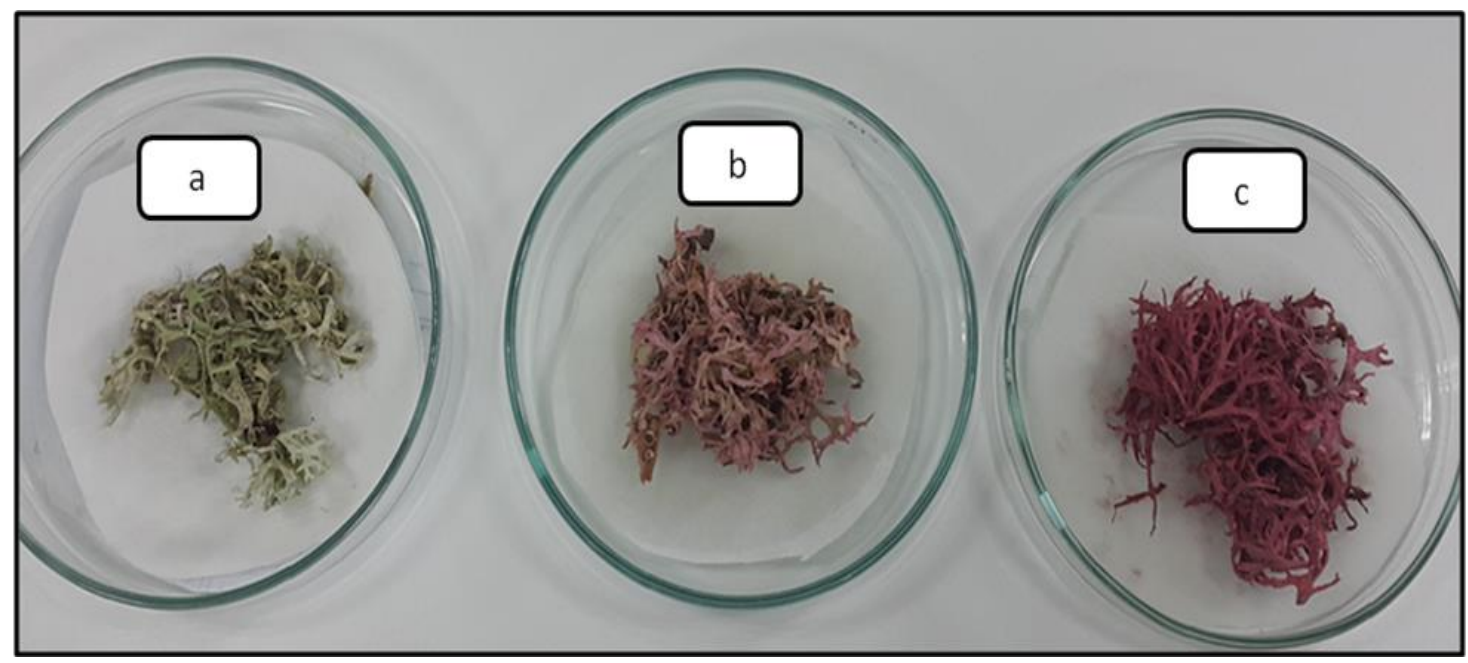

Figure 1. The photo of unloaded (a) and dye-loaded (absorbed b: $25 \mathrm{mg} / \mathrm{L}$ and c: $100 \mathrm{mg} / \mathrm{L}$ dye) E. prunastri biomass used to obtain the extract

\subsection{Scanning Electron Microscope (SEM) Analysis}

Scanning Electron Microscopy (SEM) analysis was performed at the Bilecik Seyh Edebali University Central Research Laboratory using SEM, Supra 40VP, Zeiss device to examine changes in surface morphology of lichen before and after dye removal. SEM-EDS analyzes were carried out to identify the elemental composition of the unloaded and dye-loaded lichen samples using the same device.

\subsection{Extraction Method}

Lichens are powdered with the blender (mechanical shredder) under aseptic conditions. Weighing $10 \mathrm{~g}$ of each lichen sample was subjected to 12 hours of extraction in a soxhlet device with $250 \mathrm{~mL}$ of ethanol (96\%) (Khan et al., 1988).

\subsection{Antimicrobial Activity Test}

The test microorganisms called Escherichia coli ATCC 25922 and Staphylococcus aureus ATCC 29213 strains were used for antimicrobial activity experiments. To activate the tested microorganisms, a loop of stock bacteria cultures inoculated into Mueller Hinton Broth filled tubes in the sterile conditions, and the bacteria were incubated at $35-37^{\circ} \mathrm{C}$ for $24-48$ hours. Then the activated microorganisms $(1 \mathrm{ml})$ were inoculated into Petri dishes including Mueller Hinton Agar and allowed to dry for 15-20 minutes at room temperature. For the addition of lichen extracts, $5 \mathrm{~mm}$ diameter wells were placed in Petri dishes under sterile conditions.

Each of the bacteria to be used in the study was inoculated into Nutrient Broth media in $50 \mathrm{ml}$ flasks and left in an incubator with shaking for 24 hours at $37^{\circ} \mathrm{C}$. At the end of the incubation, a bacterial suspension was prepared from the bacteria cultures, with Mc Farland at a density of $0.5\left(1.5 \times 10^{8} \mathrm{CFU} / \mathrm{mL}\right)$. The previously sterilized $24 \mathrm{ml}$ of Mueller Hinton agar was poured into Petri dishes. In the sterile conditions, $5 \mathrm{~mm}$ diameter wells were opened into the solid medium and the semi-solid Mueller Hinton agar is dropped into the wells so that the bottom of the wells is closed. The $200 \mu \mathrm{l}$ of bacterial suspension prepared according to Mc Farland 
value was inoculated into the petri dish. After inoculation, the $50 \mu 1$ of lichen extract was loaded into each well, and the Petri dishes were kept at $37^{\circ} \mathrm{C}$ for incubation of 24 hours. Lichen extracts were used in two ways such as undiluted and diluted (in 1/3 ratio). Inhibition zones formed at the end of the incubation were measured in $\mathrm{mm}$ and the lichen extracts forming less than $12 \mathrm{~mm}$ zone was considered to have no antimicrobial activity. Each experiment has been tried to duplicate (Collins et al., 1989; Wayne, 2015).

\subsection{Statistical Analysis}

Antimicrobial effects of extracts obtained from unloaded and dye-loaded lichen samples were investigated with one-way ANOVA at 0.05 significance level, SPSS 17 and Microsoft Excel Package Programs were used for statistical analysis.

\section{Results and Discussion}

In this study, the changes in the antimicrobial activity of the dye loaded and unloaded lichen extracts were investigated. For this purpose, both the lichen biomass, which removed the textile dye, and the lichen biomass not treated with dye were extracted and the changes in the antibacterial behavior of these extracts were examined. The results of the experiments are shown in Tables 1 and 2.

Table 1. The results with the test organism called Staphylococcus aureus ATCC 29213 (s *: diluted; unloaded: control group not treated with dye; dye-loaded: dye adsorbed lichen)

\begin{tabular}{cc}
\hline Lichen Extract & Inhibition Zone (mm) \\
\hline Un-loaded & $20.00 \pm 1.41$ \\
Un-loaded (s*) & $16.50 \pm 2.12$ \\
Dye-loaded & $19.50 \pm 0.71$ \\
Dye-loaded ( $\left.\mathrm{s}^{*}\right)$ & $16.50 \pm 2.12$ \\
\hline
\end{tabular}

Values are given as mean \pm standard deviation.

It was found that ethanol extracts from waste lichen biomass, which done the dye biosorption, had an antimicrobial effect on Staphylococcus aureus ATCC 29213 strain and the similar effects with the ethanol extracts obtained from the control group were observed (Table 1). Previously, Osmanağaoğlu et al. (2000) reported that the different lichen species isolated from different regions of Turkey had antimicrobial activities against Staphylococcus aureus ATCC 43300. Similarly, according to the results of this study, it was found that E. prunastri, which was the lichen type collected from Bilecik region, has an antimicrobial effect on $S$. aureus, a gram-positive bacterium (Table 1). Agboke and Esimone (2011) determined that Ramalina farinacea, a different type of lichen species, showed the maximum inhibition zone value of the clinical isolates of $S$. aureus as $19.00 \mathrm{~mm}$. The extract of the control group and the test group lichen biomass used in this study showed maximum inhibition zone values for 
the Staphylococcus aureus ATCC 29213 strain as $20.00 \mathrm{~mm}$ and $19.50 \mathrm{~mm}$, respectively (Table 1).

The antimicrobial effect of both the undiluted and diluted extracts of the dye-loaded test group on E. coli ATCC 25922 did not significantly differ from the effect of both undiluted and diluted extracts of the un-loaded control group (Tablo 2). According to the results obtained from this study was similar to the results of the previous study conducted by Şirin and Dülger (2015). The lichen species called Ramalina farinacea (L.) Ach. and Usnea intermedia (A. Massal.) showed antimicrobial activity against E. coli ATCC 25922 (Şirin \& Dülger, 2015). In this study, another lichen species called E. prunastri performed antibacterial activity against the strain E. coli ATCC 25922.

When Tables 1 and 2 are examined, it was observed that the lichen named E. prunastri has an antimicrobial effect against both gram-positive Staphylococcus aureus ATCC 29213 and gram-negative E. coli ATCC 25922 test organisms. Besides, it was found that there was no significant change in the antimicrobial activity of the extract obtained from the dye-loaded and un-loaded lichen biomass.

Table 2. The results with the test organism called Escherichia coli ATCC 25922 (s *: diluted; unloaded: control group not treated with dye; dye-loaded: dye adsorbed lichen)

\begin{tabular}{cc}
\hline Lichen Extract & Inhibition Zone (mm) \\
\hline Un-loaded & $21.50 \pm 0.71$ \\
Un-loaded $\left(\mathrm{s}^{*}\right)$ & $18.00 \pm 1.14$ \\
Dye-loaded & $20.50 \pm 0.50$ \\
Dye-loaded $\left(\mathrm{s}^{*}\right)$ & $18.00 \pm 0.48$ \\
\hline
\end{tabular}

Values are given as mean \pm standard deviation.

When the antimicrobial effects of the extracts obtained from the dye-loaded test group and the un-loaded control group of lichen biomasses effect on both microorganisms was statistically analyzed. Since the values obtained in the calculations were greater than 0.05 significance value, there was no significant difference between the antimicrobial effects of both groups.

On the other hand, SEM analysis provided detailed information about the interactions between lichen and dye. The SEM photographs of unloaded lichen and dye-loaded (with 25 $\mathrm{m} / \mathrm{L}$ dyes and $100 \mathrm{~m} / \mathrm{L}$ dyes) lichen surfaces are presented in Figure 2 (a), (b) and (c), respectively. When Figure 2 was examined, it was observed that there was a significant change in the surface morphology of lichen after dye biosorption. It was observed that the dye molecules were a presence on the surface of lichen after loaded with dye. It was assumed that this situation may have been caused by the interactions between the dye ions and functional groups on the lichen surface. As seen in Figure 2 (a, b, and c), the anionic dye 
molecules adsorbed to the positively charged lichen surface at $\mathrm{pH} 2$. Therefore, it is considered that dye molecules do not affect lichen secondary metabolites having antimicrobial effects. As a result, the antimicrobial activity of the waste lichen, where dye adsorption occurred, was not affected negatively by dye biosorption.

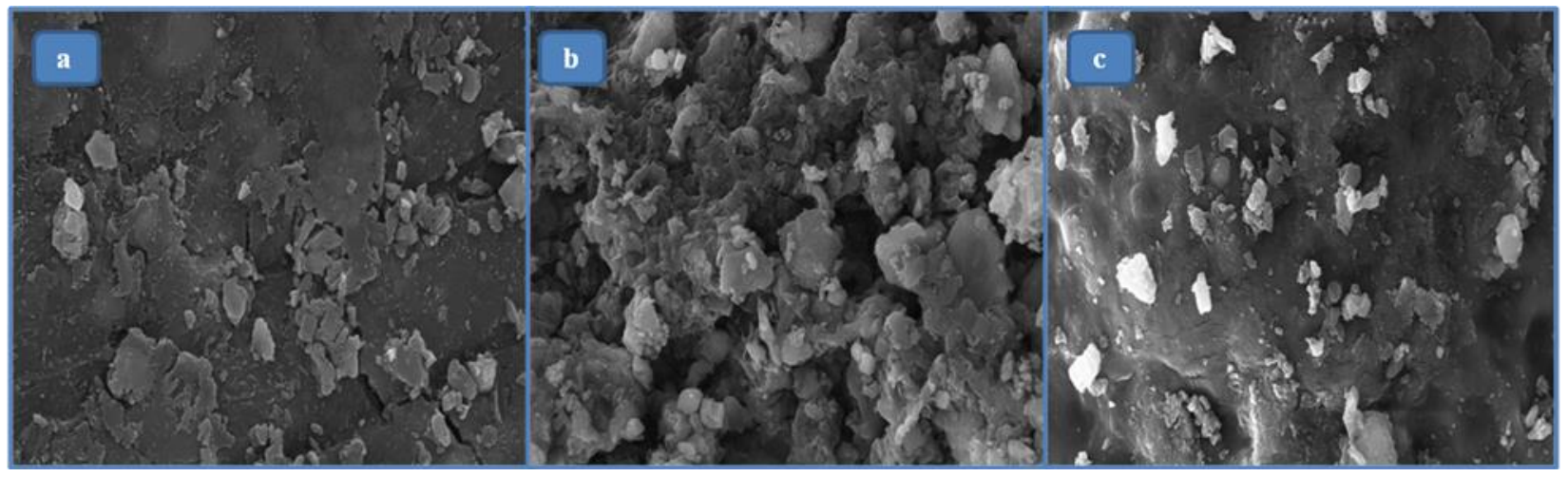

Figure 2. The SEM photos of E. prunastri (a: un-loaded; b: $25 \mathrm{mg} / \mathrm{L}$ and c: $100 \mathrm{mg} / \mathrm{L}$ dye loaded; magnification: $1000 \mathrm{X}$ and $10.00 \mathrm{KX}$ )

Figure 3 (a), (b) and (c) shows the EDX results un-loaded and dye-loaded (25 and $100 \mathrm{mg} / \mathrm{L}$ dye) lichen biomass, respectively. According to these results, the fact that the $\mathrm{Na}^{+}$element, which was not found on the un-loaded lichen surface (Figure 3 (a)), was observed on the dye-loaded lichen surface (Figure 3 (b) and (c)). It was indicated that after AR dye biosorption the dye molecules have interacted with the lichen surface because the element $\mathrm{Na}^{+}$, which was not found in the structure of lichen, was found in the molecular structure of the dye AR used in this study (Gül et al., 2019).

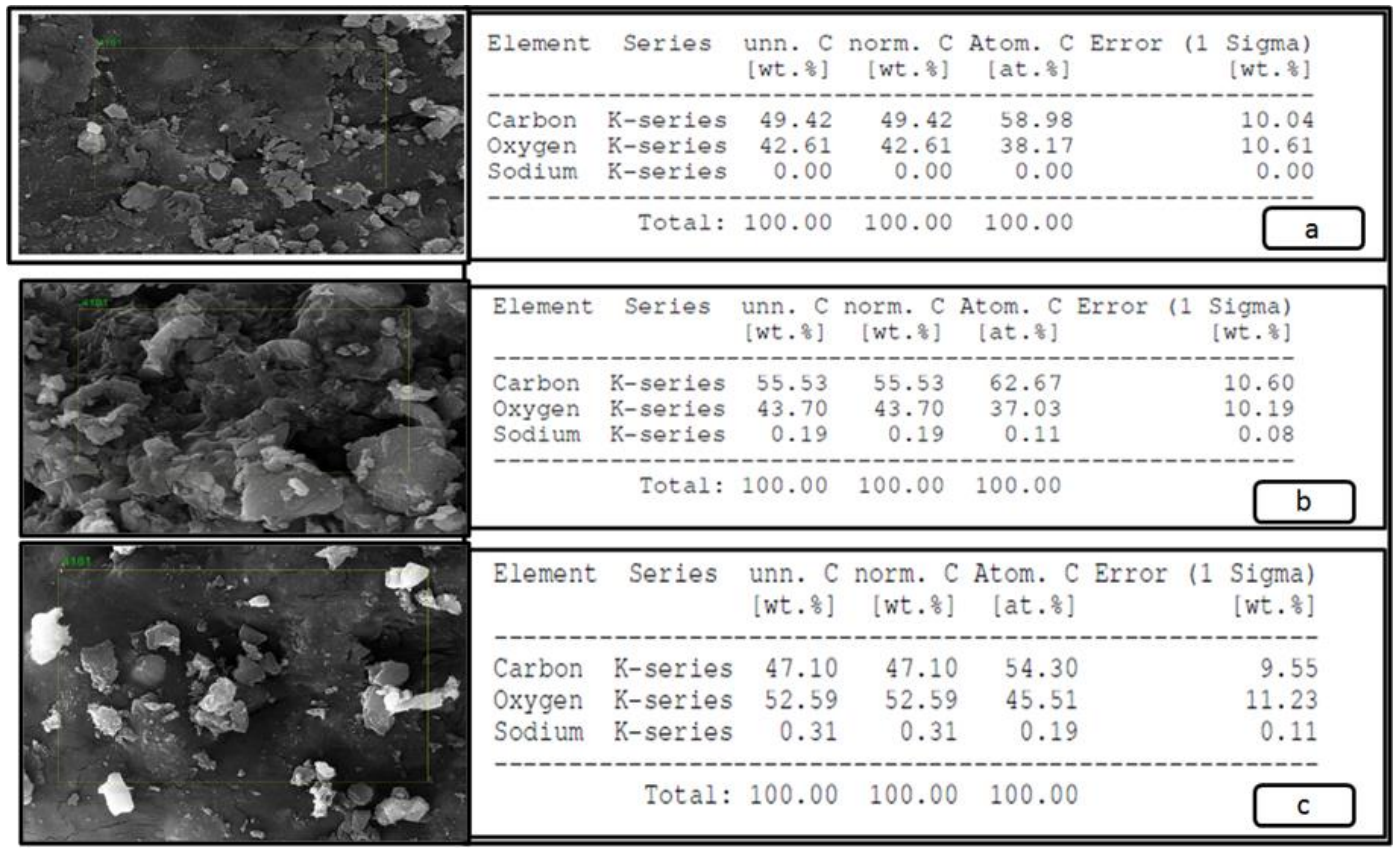

Figure 3. The EDX results of E. prunastri un-loaded (a) and dye-loaded (b: $25 \mathrm{mg} / \mathrm{L}$ and c: $100 \mathrm{mg} / \mathrm{L}$ dye removal) 
According to the results of this study, the significant data were obtained by investigating the antimicrobial effect of ethanol extracts of E. prunastri lichens naturally grown in Bilecik province. In addition to this, it has been determined that the dye-loaded biomass formed after the use in the removal of this lichen had the same effect as the un-loaded lichen biomass. There are some studies in the literature showing the antimicrobial activity of lichen species different from E. prunastri used in this study (Yilmaz et al., 2004; Saenz et al., 2006; Balaji \& Hariharan, 2007; Güneş Yücel \& Özyiğitoğlu, 2018). On the other hand, since there is no study in the literature about the antimicrobial activity of waste biomass, which performed dye removal, this study is the first report to investigate the antimicrobial activity of dye-loaded lichen obtained from effective treatment of dye-contaminated wastewater.

The activities of the antibiotics that are currently available are decreasing due to the unconscious use and microorganisms that gain resistance day by day. Further researches and discoveries of natural pharmaceutical raw materials will allow the next generation to reduce the burden of drug problems in disease control. Also, nowadays the production of products having antimicrobial properties gain importance in the industry. Today the costumers will prefer the goods having antimicrobial property to avoid infections. The results of this study support the use of dye-loaded lichen wastes that can be used to obtain antimicrobial agents after dye contaminated wastewater treatment. It is concluded that these waste lichen extracts may be used to produce antimicrobial products such as clothes against pathogens. This study is a preliminary study showing that lichen biomass, which is used in the treatment of wastewater containing textile dyes and released after treatment, can be used to obtain an extract containing antimicrobial activity. In future studies, it is suggested to prepare the waste lichen extracts used with different solutions and to do further antimicrobial activity tests such as MICs. And, also it is recommended that to produce fabrics treated with the lichen extracts having the antimicrobial function for further researches.

\section{Acknowledgments}

This study is partially supported by the review of Bilecik Seyh Edebali University Scientific Research Projects (2017-02.BŞEÜ.12-01).

\section{References}

Agboke, A. A., \& Esimone, C. O. (2011). Antimicrobial evaluation of the interaction between methanol extract of the lichen, Ramalina farinacea (Ramalinacea), and Ampicillin against clinical isolates of Staphylococcus aureus. Journal of Medicinal Plants Research, 5(4), 644-648.

Balaji. P., \& Hariharan, G. N. (2007). In vitro Antimicrobial Activity of Parmotrema raesorediosum Thallus Extracts. Research Journal of Botany, 2(1), 54-59. https://doi.org/10.3923/rjb.2007.54.59

Çobanoğlu, G., Dilsizoğlu, A., Kavuncuoğlu, Z., \& Oba, D. (2004). Eski ve Yeni Kullanım Alanları Bilinmeyen Yönleriyle Likenler. Bilim ve Teknik, 86-89.

Collins, C. H., Lyne, P. M., Grange, J. M., \& Falkinham, J. O. (1989). Microbiological 
Methods. 6th edition, Oxford University Press London.

Gül, Ü. D., Taştan, B. E., \& Bayazit, G. (2019). Assessment of algal biomasses having different cell structures for biosorption properties of acid red P-2BX dye. South African Journal of Botany, 127, 147-152. https://doi.org/10.1016/j.sajb.2019.08.047

Güneş, Y. D., \& Özyiğitoğlu, G. (2018). Ramalina calicaris (L.) Fr. Liken Türünün Antibakteriyel ve Antioksidan Aktivitesi. Marmara Fen Bilimleri Dergisi, 3, 269-275. https://doi.org/10.7240/marufbd.402055

Halici, M., Odabasoglu, F., Suleyman, H., Cakir, A., Aslan, A., \& Bayir, Y. (2005). Effects of water extract of Usnea longissima on antioxidant enzyme activity and mucosal damage caused by indomethacin in rats. Phytomedicine, 12, 656-662. https://doi.org/10.1016/j.phymed.2004.06.021

Hanus, L. O., Temina, M., \& Dembitsky, V. M. (2008). Antibacterial and antifungal activities of some phenolic metabolites isolated from the lichenized ascomycete Ramalina lacera. Natural Product Communications, 3, 233-236. https://doi.org/10.1177/1934578X0800300226

Khan, N. H., Rahman, M., \& Nur-e-Kamal, M. S. (1988). Antibacterial activity of Euphorbia thymifolia Linn. Indian J. Res, 87, 395-397.

Necip, A., \& Isik, M. (2019). Bioactivities of Hypericum perforatum L. and Equisetum arvense L. fractions obtained with different solvents. International Journal of Life Sciences and Biotechnology, 2(3), 221-230. https://doi.org/10.38001/ijlsb.636502

Oran, S., \& Öztürk, G. (2006). Lichens of Gemlik, İznik, Mudanya and Orhangazi districts in Bursa province (Turkey). Turkish Journal of Botanyi., 30, 231-250.

Osmanağaoğlu, Ö., Yıldız, A., \& Saçılık, S. C. (2000). Turkiye'deki Farklı Bolgelerden İzole Edilen Likenlerin Antimikrobiyal Aktiviteleri. Turk Mikrobiyol Cem Derg, 30, 17-19.

Özenoğlu, S., Aydoğdu, G., Dinçsoy, A. B., Taghidizaj, A. A., Derici, K., Y1lmaz, K., Aras, S., \& Duman, D. C. (2013). Evaluation of the impact on different types of human cancer cell of lichen secondary compounds. Türk Hijyen ve Deneysel Biyoloji Dergisi, 70(4), 215-226. https://doi.org/10.5505/TurkHijyen.2013.37167

Rankovic, B. R., Misic, M., \& Sukdolak, S. (2007). Antimicrobial Activity of extracts of the lichens Cladonia furcata, Parmelia caperata, Parmelia pertusa, Hypogymnia physodes and Umbilicaria polyphylla. British Journal of Biomedical Science, 64, 1-6. https://doi.org/10.1080/09674845.2007.11732776

Saenz, M. T., Garcia, M. D., \& Rowe, J. G. (2006). Antimicrobial activity and phytochemical studies of some lichens from south of Spain. Fitoterapia, 77, 156-159. https://doi.org/10.1016/j.fitote.2005.12.001

Şekerli, M., Kılıç, N., \& Cansaran Duman, D. (2017). The molecular mechanisms of the effect of anticancer activity on lichen metabolites. Türk Hijyen ve Deneysel Biyoloji Dergisi, 74(1), 95-102. https://doi.org/10.5505/TurkHijyen.2016.24650 


\section{Macrothink}

Şirin, N., \& Dülger, B. (2015). Ramalina farinacea (L.) Ach. ve Usnea intermedia (A.Massal.) Jatta Likenlerinin Antimikrobiyal Aktiviteleri Üzerine Araştırmalar. Düzce Üniversitesi Bilim ve Teknoloji Dergisi, 3, 340-349.

Wayne, P. A. (2015). CLSI (Clinical and Laboratory Standards Institute), Performance Standards for Antimicrobial Disk Susceptibility Test; Approved Standard, CLSI document M02-A11, 11th edition, Clinical and Laboratory Stantards Institute.

Yilmaz, M., Türk, A. O., Tay, T., \& Kivanç, M. (2004). The Antimicrobial Activity of Extracts of the Lichen Cladonia foliacea and Its ( $\breve{G})$-Usnic Acid, Atranorin, and $\begin{array}{llll}\text { Fumarprotocetraric Acid } \quad \text { Constituents. Naturforsch, } & \text { 59, } 254 .\end{array}$ https://doi.org/10.1515/znc-2004-3-423

\section{Copyright Disclaimer}

Copyright for this article is retained by the author(s), with first publication rights granted to the journal.

This is an open-access article distributed under the terms and conditions of the Creative Commons Attribution license (http://creativecommons.org/licenses/by/4.0/). 